\title{
IGF2-AS wt Allele
}

National Cancer Institute

\section{Source}

National Cancer Institute. IGF2-AS wt Allele. NCI Thesaurus. Code C114313.

Human IGF2-AS wild-type allele is located in the vicinity of $11 \mathrm{p} 15.5$ and is approximately 8 $\mathrm{kb}$ in length. This allele, which encodes IGF2 Antisense RNA and may encode putative insulin-like growth factor 2 antisense gene protein, plays a role in Wilms tumor and may be involved in embryotic kidney development. 